\title{
VOJNA LJEČILIŠTA NA KVARNERU U AUSTRO-UGARSKOJ MONARHIJI I BRIGA ZA UNAPREĐENJE ČASNIČKOG ZDRAVLJA
}

\author{
MILITARY HEALTH RESORTS IN KVARNER IN \\ THE AUSTRO-HUNGARIAN MONARCHY AND \\ CARE FOR IMPROVING OFFICER HEALTH
}

\author{
Jasenka Kranjčević", Amir Muzur**
}

\begin{abstract}
SAŽETAK
Zdravlje časnika (kao i cijele vojske) izloženo je dodatnim rizicima zbog izvršavanja različitih za život opasnih zadaća $i$ to za potrebe države. Stoga nije neobično da država vodi brigu o zdravlju svojih časnika (kao $i$ vojske) kroz sustav vojnomedicinske skrbi ili specijaliziranih društava koji pružaju medicinske/zdravstvene usluga u vojnim, odnosno časničkim lječilištima [Militärkurhaus/Offizierskurhaus]. Predmet ovog rada je međuodnos arhitekture $i$ pružanja vojnomedicinskih usluga časničkih/vojnih lječilišta koje je izgradilo Društvo Bijeli križ [Gesellschaft vom Weißen Kreuze] na Kvarneru krajem Ig. i početkom 20. stoljeća. Istraživanje se temelji na podacima prikupljenim iz austrijskih arhitektonskih, medicinskih i turističkih časopisa te godišnjaka austrijskog Društva Bijeli križ. Rezultati istraživanja pridonose boljem poznavanju unapređenja zdravlja časnika, razvoju arhitekture lječilišnih zgrada [Kurhaus] te cjelokupnoj povijesti medicine i lječilišnog turizma na prostoru hrvatskog Jadrana.
\end{abstract}

Ključne riječi: povijest medicine, zdravstveni turizam, vojna lječilišta, Društvo Bijeli križ, Opatija, Mali Lošinj

* Institut za turizam, Zagreb, Hrvatska.

** Katedra za društvene i humanističke znanosti u medicini, Sveučilište u Rijeci, Medicinski fakultet / Katedra za javno zdravstvo, Sveučilište u Rijeci, Fakultet zdravstvenih studija, Rijeka, Hrvatska.

Adresa za dopisivanje: Jasenka Kranjčević, Institut za turizam, Vrhovec 5, 10000 Zagreb, Hrvatska. ORCID ID: https://orcid.org/0000-0002-5594-9868.E-pošta: jasenka.kranjcevic@iztzg.hr. 


\section{UMJESTO UVODA: LJEČILIŠNA MJESTA, LJEČILIŠTA I UNAPREĐENJE ZDRAVLJA}

Drugu polovicu 19. i početak 20. stoljeća karakterizirali su, između ostalog, razvoj tehnologije i medicine, a višak slobodnog vremena utjecao je na razvoj turizma. To je vrijeme kada se je sve jasnije izražavala briga o zdravlju, što je vidljivo i po proglašenim lječilišnim mjestima [Kurort] koja su sve više dobivala na značenju. Stoga je na prostoru Europe i sjeverne Afrike (južni Mediteran) započela njihova inventarizacija izdavanjem kataloga. Osim osnovnih podataka o lječilišnim mjestima (lokacija, prometna dostupnost, cijena i dr.) opisivana su i njihova specifična balneološka svojstva. Objedinjeni katalozi služili su kao pomoć liječnicima ili oboljelima za odabir lječilišnog mjesta, tj. gdje i kada unaprijediti zdravlje ili liječiti određene bolesti. Evidencijom na prostoru Europe, lječilišta su polako dobivala međunarodnu prepoznatljivost, kvalifikaciju i rangiranje. Katalozi su uglavnom tiskani na njemačkom i engleskom jeziku i bili su opsega od 300 pa i više od 600 stranica. ${ }^{1}$ Oni koji su imali mogućnosti, mogli su brinuti o unapređenju svoga zdravlja.

U to vrijeme na cijelom teritoriju Austro-Ugarske Monarhije mali je broj naselja proglašen lječilišnim mjestom i to nakon ispunjavanja strogih propisanih uvjeta. ${ }^{2}$ Dobivanjem takva statusa lječilišna su mjesta uvrštena na zajedničku listu i postala zanimljiva liječnicima, bolesnicima, turistima, ali i investitorima. Investitori su bili različite korporacije, ${ }^{3}$ društva,${ }^{4}$ gradovi ${ }^{5}$ i pojedinci.

Lječilišna mjesta s prostora današnje Hrvatske (Jadran i kontinentalni dio), iako brojčano malobrojna, zbog specifičnih balneoloških svojstva bila

1 Da bi se dobio uvid o važnosti inventarizacije lječilišta (a može se reći počeci globalizacije lječilišta na prostoru Europe s kraja 19. i početka 20. stoljeća), ovdje se navode samo neki katalozi: Reimer, Hermann Andreas (1881), Klimatische Winterkurorte, Berlin; Reimer, Hermann Andreas (1889), Handbuch der speziellen Klimatotherapie und Balneotherapie mit besonderer Rücksicht auf Mittel-Europa zum Gebrauch für Aerzte, Berlin; Flechsig, Robert Ferdinand (1889), Bäder-Lexikon: Darstellung aller bekannten Bäder, Heilquellen, Wasserheilanstalten und klimatischen Kurorte Europas und des nördlichen Afrikas in medizinischer, topographischer, ökonomischer und finanzieller Beziehung, Leipzig; Linn, Thomas (1893), The health resorts of Europe: a medical guide to the mineral springs, climatic, mountain, and seaside health resorts, milk, whey, grape, earth, mud, sand and air cures of Europe, London; Diem, Karl (1914), Österreichisches Bäderbuch: offizielles Handbuch der Bäder, Kurorte, und Heilanstalten Österreichs, Berlin/Wien.

2 Do Prvoga svjetskog rata na prostoru Austro-Ugarske Monarhije proglašeno je oko 250 lječilišnih mjesta.

3 Na prostoru hrvatskog Jadrana najveće korporacije su Društvo Južnih željeznica i Austrijsko parobrodarsko društvo Lloyd.

4 Društvo Crveni križ, Društvo Zlatni križ i dr.

5 Grad Bečidr. 
su prepoznata između brojnih u Monarhiji i Europi. Na hrvatskom Jadranu u drugoj polovici i9. i na početku 20. stoljeća proglašena su sljedeća lječilišna mjesta: Hvar ı868., Opatija I889., Veli i Mali Lošinj ı892., Lovran 1905. i Crikvenica 1906. godine. Iz kontinentalnog dijela Hrvatske ističu se lječilišna mjesta kao što su Topusko ${ }^{6}$, Lipik, Daruvar, Krapinske Toplice.

Od svih proglašenih lječilišnih mjesta na prostoru današnje Hrvatske, Opatija je zbog prometne dostupnosti, komunalne infrastrukture, novoizgrađenih atraktivnih lječilišno-turističkih zgrada, doživjela vrtoglavi uspon lječilišnog turizma i u kratkom vremenu na prostoru Monarhije postala prestižno morsko lječilišno mjesto.?

Zbog brojnih i dugotrajnih ratova na prostoru cijele Europe tijekom I9. stoljeća, sve je više dolazila do izražaja briga o zdravlju kako cijele vojske tako i časnika jer su izvršavali različite za život opasne zadaće. Stoga su države sve više počinjale voditi brigu o zdravlju svojih časnika (kao i cijele vojske) preko sustava vojnomedicinske skrbi ili specijaliziranih udruženja. ${ }^{8}$

Vojska Austro-Ugarske Monarhije imala je organiziranu medicinsku skrb u postrojbama (bataljunima), ali ne svagdje jednako kvalitetno. ${ }^{9}$ Briga o zdravlju časnika nije bila ograničena samo na korištenje vojnomedicinskih institucija već se polako širila na pružanje usluga u vojnim/časničkim lječilištima [Militärkurhaus/Offizierskurhaus] i to u naseljima koja su proglašena lječilišnim mjestima (morska, zimska, planinska, klimatska i sl.). Časnička/vojna lječilišta zgrade su specifične namjene jer nisu niti isključivo zdravstvene, niti isključivo ugostiteljske namjene, a namijenjene su isključivo za unapređenje zdravlja vojnih osoba.

U dosadašnjim znanstvenim istraživanjima o lječilišnim mjestima na prostoru hrvatskog Jadrana donekle su zanemarene zgrade vojnih/časničkih lječilišta s kraja I9. i početka 20. stoljeća povezivanjem arhitekture i

Lječilište Topusko je 2018. slavilo 200 godina organiziranoga suvremenog lječilišta.

7 O turističkom prometu Istre i Kvarnera vidi u: Blažević, I. (1987), Povijest turizma Istre $i$ Kvarnera, Otokar Keršovani, Opatija.

8 Poticaj za osnivanje organizacije Crvenog križa bilo je katastrofalno stanje ranjenika na bojištu nakon bitke kod Solferina (Italija) gdje se austrijska vojska sukobila s francusko-talijanskom vojskom. Nakon petnaest sati bitke, na bojištu je bilo 40.000 ranjenika koji su trebali medicinsku skrb.

9 Krajem 19. stoljeća nije svagdje bilo dovoljno vojnih liječnika te su negdje civilni liječnici radili i za potrebe vojske. Posebna znanja iz vojne kirurgije vojni liječnici stjecali su tijekom šestomjesečnog tečaja u Beču. Zatim su se u okviru tromjesečne obuke u bolnicama zajedničke vojske upoznavali s poslovanjem i organizacijom vojnih bolnica. Od 1884. mogli su se usavršavati na Medicinskom fakultetu u Budimpešti, a poslije i u Cluj-Napoci (danas Rumunjska). Pomoćno medicinsko osoblje obučavalo se u školama vojnih postrojbi, a potrebnu praksu dobivalo je u bolnicama zajedničke vojske. 
vojnomedicinska usluga. Stoga je predmet ovog rada međuodnos arhitekture i pružanja vojnomedicinske usluge časničkih/vojnih lječilišta koje je izgradilo Društvo Bijeli križ10 [Gesellschaft vom Weißen Kreuze] na Kvarneru krajem I9. i početkom 20. stoljeća. Za istraživanje je korištena povijesna metoda jer se istraživanje temelji na analizi i usporedbi povijesnih podataka prikupljenih iz austrijskih arhitektonskih, medicinskih i turističkih časopisa te godišnjaka austrijskog Društva Bijeli križ s kraja 19. i početka 20. stoljeća.

Cilj je ovoga rada da se preko primjera časničkih lječilišta, kao zgrada specifične namjene, utvrdi povezanost arhitekture i medicinske usluge praćenjem odabira lokacija, arhitektonskih obilježja i funkcija te pružanja zdravstvenih/medicinskih usluga. Utvrđivanjem navedenih činjenica s kraja I9. i početka 20. stoljeća planira se doći do spoznaja o tadašnjoj društvenoj brizi za unapređenje zdravlja pripadnika vojske Austro-Ugarske Monarhije. Kao primjer zgrada vojnih lječilišta odabrane su one koje je gradilo Društvo Bijeli križ na području Kvarnera. ${ }^{11}$ Za istraživanje vojnih lječilišta (lokacija, arhitektura, tlocrt, materijal, vanjsko i unutarnje oblikovanje) korišteni su podatci iz tadašnjih austrijskih građevinsko-arhitektonskih ${ }^{12}$, medicinskih ${ }^{13}$ i turističkih ${ }^{14}$ časopisa te godišnjaka ${ }^{15}$ Društva Bijeli krǐ̌.

10 Društvo Bijeli križ osnovano je 2. veljače 1882. Društvo se do 1907. zvalo Austrijsko društvo Bijeli križ [Österreichische Gesellschaft vom Weißen Kreuze] a od 1908. do 1918. Carsko i kraljevsko društvo Bijeli križ [K. k. Gesellschaft vom Weissen Kreuze]. Cilj je Društva Bijeli križ bila skrb o pripadnicima carske i kraljevske vojske Austro-Ugarske Monarhije, koji su pretrpjeli ratne ozljede.

11 Na Kvarneru je, u Crikvenici, u zgradi bivšega pavlinskog samostana, 1895. uređeno vojno lječilište. Zgradu je otkupio nadvojvoda Josip te je dao urediti vojno lječilište s 23 sobe. Lječilište je 1897. preseljeno u veliku novosagrađenu vilu Mira, a bivše vojno lječilište preuređeno je u Ladislavov dječji dom. S obzirom na to da lječilište u Crikvenici nije bilo u vlasništvu Društva Bijeli križ, nije bilo predmetom ovog istraživanja. Vidi: *** (1909), Cirkvenica - Seebad und klimatischer Kurort, Der Fremdenverkehr 16, 4-6. i Uremović V., Vukelić, I., Gobić, J. (2006), Počeci i razvoj talasoterapije i zdravstvenog turizma u Crikvenici, Acta med-hist Adriat 2006, 4(2), 247-258.

12 Časopis: Wiener Bauindustrie Zeitung: Organ für Architekten, Ingenieure, Baumeister usw. u. alle Bauinteressierten, 1883. - 1916.;

13 Časopisi: Der Militärarzt: Internationales Organ für das gesamte Sanitätswesen der Armeen, 1867. - 1918.; Wiener Medizinische Wochenschrift, 1851. - 1944.; Zentralblatt für Thalassotherapie, Klimatologie, Balneologie und verwandte Wissenzweige: Offizieles Organ des Vereines der Ärzte in Abbazia, des Vereines der Ärzte in der deutschen Nordseebäder und des Vereines der Badeärzte der Ostsee, 1909.-1911.; Kur- und Bade-Zeitung der österreichischen Riviera, 1906. - 1914.; Österreichische Badezeitung: Organ für die Interessen der europäischen Kurorte und des Kurpublikums, 1872. - 1886.;

14 Časopis: Fremdenverkehr: Illustrierte Wochenschrift zur Förderung der Verkehrsinteressen Österrreichs, 1908. - 1914.

15 Godišnjak: Jahrbuch der k. k. Gesellschaft vom Weissen Kreuze. 


\section{DRUŠTVO BIJELI KRIŽ I VOJNA LJEČILIŠTA}

Društvo Bijeli križ osnovano je I882. s ciljem njegovanja i unapređenja zdravlja pripadnika vojske (posebno časnika) Austro-Ugarske Monarhije. Od rgog. Društvo djeluje na prostoru cijele Monarhije, a ne samo u austrijskom dijelu. Društvo se bavilo i prodajom mineralne vode te je zbog toga toliko financijski ojačalo da je do Igr2. izgradilo ukupno I4 zgrada časničkih lječilišta na prostoru današnje Češke, Slovenije, Austrije, Italije, Hrvatske te Bosne i Hercegovine. Osim časnika, lječilišta su mogli koristiti kadeti te drugi pripadnici vojske, a teže oboljeli mogli su uza se imati pratnju (najčešće članovi obitelji). Iako se radilo o zgradama malih smještajnih kapaciteta, do kraja 1913. u lječilišnim zgradama Društva ukupno je boravilo 29.300 osoba. ${ }^{16}$ Najstarija zgrada Društva Bijeli križ izgrađena je i88ı. u Češkoj u Marienbadu (danas Marianske Lazne), kao pilot-projekt prije službenog osnivanja Društva, s ciljem provjere opravdanosti daljnje gradnje vojnih lječilišta. Već nakon godine dana rada zgrada je pokazala ekonomsku opravdanost poslovanja te je službeno osnovano Društvo i882. Uslijedila je gradnja novih zgrada vojnih lječilišta Društva Bijeli križ, uglavnom u austrijskom dijelu Monarhije: Bad Hall u Tirolu, i883. (danas Austrija), Merano i886. (danas Italija), Opatija (Abazzia) I888. (danas Hrvatska), Rohitsch-Sauerbrunn (Rogaška Slatina) I89i. (danas Slovenija), Arco I892. (danas Italija), Karlsbad (Karlovy Vary) 1896. (danas Češka), Portorose (Portorož) I897. (danas Slovenija), Gräfenberg I898. (danas Njemačka), Baden 1906. (danas Ausztrija), Čikat (Cigale) 1907. na Lošinju (danas Hrvatska), Ilidža kod

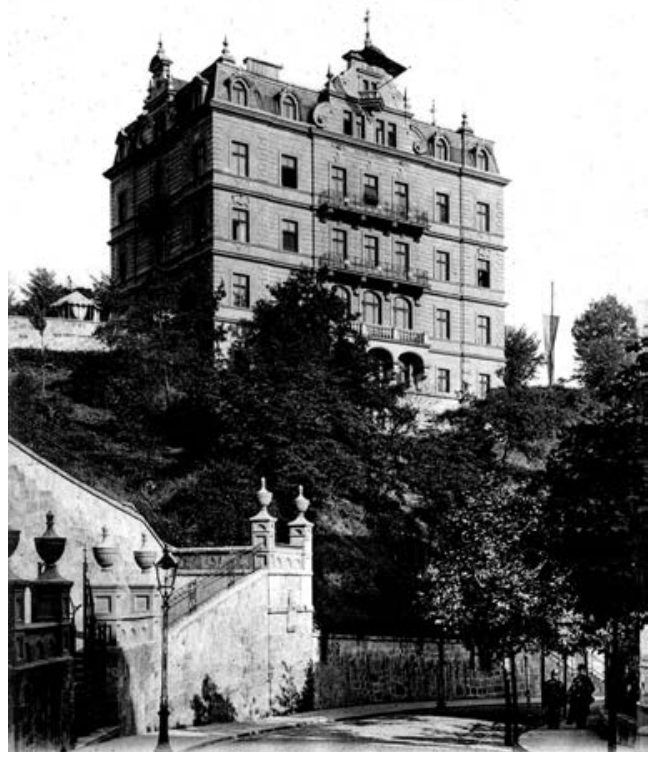

Slika r. Karlovy Vary (njem. Karlsbad), Češka, Časničko lječilište Društva Bijeli križ. Izvor: Razglednica, privatna zbirka

16 K. k. Gesellschaft vom Weissen Kreuze (1914), Jahrbuch der K. k. Gesellschaft vom Weissen Kreuze (Wien: Selbst Verlag, 93. 


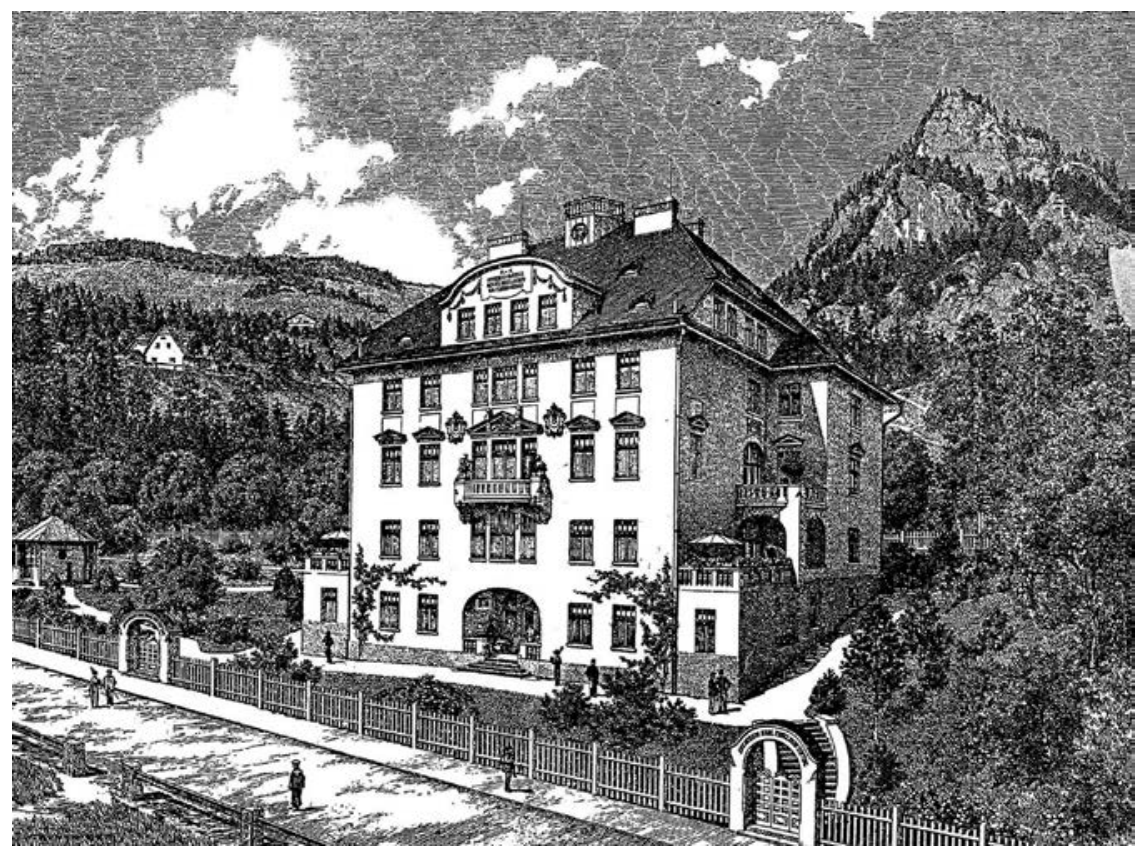

Slika 2. Breitenstein, Semmering, Austrija, Časničko lječilište Društva Bijeli križ. Izvor: K. k. Gesellschaft vom Weissen Kreuze (I9I4), Jahrbuch der K.K.

Gesellschaft vom Weissen Kreuze, Beč

Sarajeva 1907. (danas Bosna i Hercegovina) te Franzenbad (Františkovy Lázne) I9ı2. (danas Češka).

Značajan broj zgrada časničkih lječilišta projektirao je arhitekt Maria Wurm von Arnkreuz. ${ }^{17}$ Najviše zgrada projektirao je za Društvo Bijeli križ, ali je projektirao i časnička lječilišta u Beču te Vatra Dornei u Rumunjskoj koja nisu bila pod ingerencijom Društva. Vojna lječilišta Društva Bijeli križ građena su u pravilu u prestižnim proglašenim lječilišnim mjestima, a odabir lokacija vezan je za sportsko-rekreacijske građevine i površine (teniska igrališta, kupališta, šetnice i dr.).

Iz navedenog vidljivo je da je Društvo na prostoru Hrvatske gradilo vojna lječilišta samo na Kvarneru. Da je vojska unapređivala svoje zdravlje i u

17 Alois Maria Wurm-Arnkreuz (Beč, 26. 1. 1843. - Beč, 3. 2. 1920.), arhitekt, školovao se u Münchenu i Beču. Rani uspjesi doveli su ga do iznimno poznatih narudžbi u Beču, a 1870. i do nekih spektakularnih građevinskih projekata u Moskvi. Izgradio je niz prestižnih zgrada, osobito u središtu Beča. Bio je potpredsjednik časničkog Društva Bijeli križ za koje je projektirao brojna časnička lječilišta diljem Monarhije. Dobio je brojne ordene, nagrade i plemićki status. Izvor: http://www.architektenlexikon.at/de/706.htm 


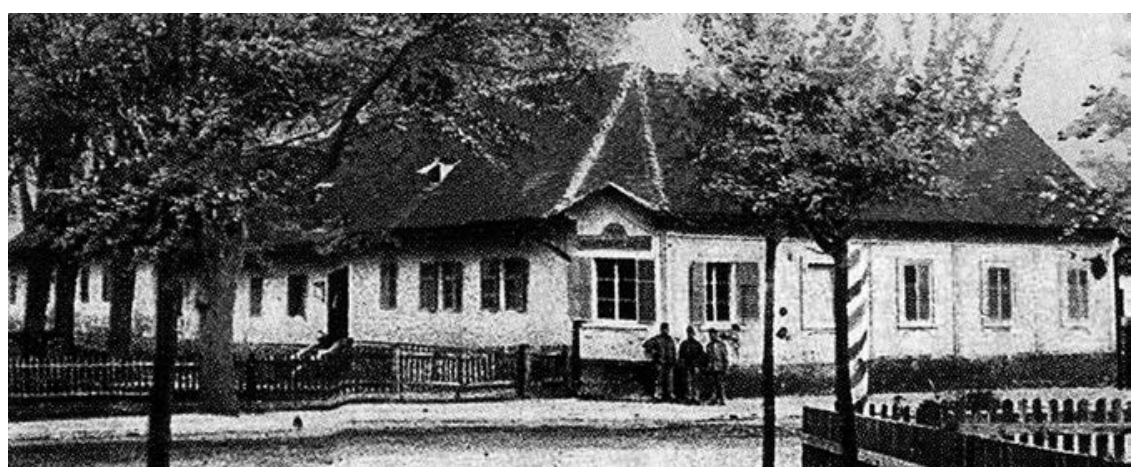

Slika 3. Topusko, Vojničke kupke. Izvor: Lipovšćak, Đurđa (2002.)

lječilišnim mjestima u kontinentalnoj Hrvatskoj upućuju nas fotografije i njihove monografije poput onih iz Topuskog.

\section{Vojno lječilište Društva Bijeli križ i liječnici u Opatiji}

Na primjeru opatijskoga vojnog lječilišta Društva Bijeli križ promotrit će se pobliže kako su takve zgrade i institucije izvorno funkcionirale, što su nudile i kakvom su medicinsko-ugostiteljskom misijom bile vođene.

Podsjetimo na samome početku da je Opatija kao turistička destinacija "otkrivena" I840-ih, ali da se njezin zdravstveno-turistički potencijal počeo koristiti tek četrdesetak godina poslije, zahvaljujući ponajprije investicijama i sustavnoj promidžbi glavnog ravnatelja Društva južnih željeznica Friedricha Juliusa Schülera i njegovih „ciljanih“ gostiju - bečkog kirurga Theodora Billrotha, bavarskog internista Maxa Josepha Örtela i, osobito, štajerskog balneologa Juliusa Glaxa. ${ }^{18}$ Naravno, Opatiju su obogatili i prinosi brojnih lokalnih i stranih medicinskih i ljekarničkih izumitelja (Grgurina, Fodor, Sternbach i dr.), inovatora zdravstveno-turističke ponude (Zanderov institut Isora Steina ili dijetetski sanatorij Béle Gámána), uspješnih voditelja sanatorija (Szegő) ili entuzijasta koji su neumorno mjerili, bilježili, dokazivali i razglašavali kvalitetu opatijske klime (Franz Tripold). Ipak, bez inicijalnoga financijskog impulsa Društva Južnih željeznica, koje su je pretvorile u svoj najvažniji projekt, Opatija se ne bi mogla tako brzo razvijati i tako snažno zasjeniti slična češka, austrijska, mađarska i talijanska lječilišta.

U konstelaciji potpore vrhunskih medicinskih autoriteta, utjecajnog plemstva, pa i samoga dvora, nije čudno da se, dakle, Opatija I880-ih dotad

18 Glax, J. (1909), Wintercurort und Seebad Abbazia - ein Führer für Curgäste, Abbazia te Glax, J. (1909), Zimsko lječilište i morsko kupalište Opatija: Putovogja za lječilišne gostove, Opatija. 
i otad neviđenim tempom širila - kako fizički, tako i ugledom. Prvu ordinaciju (izvan sanatorijskih) I884. otvorio je mađarski Židov Albert Szemere. Iste je godine otvoren hotel Kvarner [Quarnero] (projektant arhitekt Franz Wilhelm, projektant pregradnje rgog. arhitekt Alfred Wildhack), u početku zamišljen kao sanatorij za „bolesne na prsima“, da bi ubrzo promijenio namjenu u hotel. U naletu gradnji novih smještajnih zgrada i njihovih depandansi, Društvo Južnih željeznica ljeti i888. otvara u predjelu poznatom kao Slatina, nedaleko od ceste koja vodi prema Iki i Lovranu, i "stambenu zgradu broj 5 “ [Wohngebäude V] koju odmah po izgradnji, a u povodu 40. godišnjice vladavine cara i kralja Franje Josipa I., daruje Društvu Bijeli križ. ${ }^{19}$ Ovaj tzv. časnički sanatorij [Offizierskurhaus/Militärkurhaus] bio je kapacitetom malen (za I4 - I6 gostiju) i nalazio se u dijelu grada udaljenom od povijesne, odnosno nove ugostiteljske jezgre (Sv. Jakov odnosno Kvarner). Međutim, već do kraja stoljeća bit će podignuto više značajnih zdanja za potrebe lječilišta: I888. sanatorij Quisisana (danas hotel Opatija, projektant arhitekt Friedrich Sigmund), I889. hotel Slatina (poslije 1925. spojen s bivšim vojnim lječilištem), I89r., odnosno 1894. dvije vile grofice Angelique Keglevich (donedavno Policijska postaja, odnosno restoran Kamelija), I898. Sanatorij za državne činovnike (Društvo Zlatni križ, projektant arhitekt Max Fabiani, danas Dom zdravlja), a I899. vila Frieda (projektant arhitekt Carl Seidl, investitor štajerski pivski industrijalac Johann Peter Reininghausa, 1818. - I90I., oca Marije-Mitzi, žene dr. Ignaza Schwarza koji je vodio lječilište Quisisana). ${ }^{20}$

Iako je zgrada vojnog lječilišta bila u funkciji od i888., podružnica Društva Bijeli križ u Opatiji osnovana je tek 23. travnja I9O2. Članovi glavnog odbora bili su Friedrich v. Pollini, Guido Wachter, Alfred pl. von ManussiMontesole, Anton Perisić, Artur von Schmidt-Zabierow, ${ }^{21}$ Spiro Peručić, Lazar Lucich i Joan Ratković. ${ }^{22}$

Zgrada vojnog lječilišta je, kao i većina smještajnih kapaciteta Opatije za austrijske uprave, bila otvorena gotovo cijele godine: zapravo, suprotno

19 Zakošek, B. (2005), Opatijski album: dugo stoljeće jednog svjetskog lječilišta. Rijeka. Državni arhiv u Rijeci, 126.

20 Radović Mahečić, D. (2002), Preobrazba Opatije 1882. - 1897.: počeci turističke arhitekture, Radovi IPU 26, 132-148

21 Glavar kotara Volosko. Vilu u kojoj je stanovao projektirao je arhitekt Carl Seidl, a smještena je do današnje općinske vijećnice.

22 *** (1888), Das neue Officier-Curhaus in Abbazia, Wiener Bauindustrie Zeitung, VI (2), 15; *** (1892), Wohngebaude in Slatina, Abazia, Allgemeine Bauzeitung 75, tafel 23.; *** (1907), Rundgang durch Abbazia Humanitäranstalten, Kur-und Bade-Zeitung der österreichischen Riviera 2(19),1-3; K. k. Gesellschaft vom Weissen Kreuze (1912) Jahrbuch der K. k. Gesellschaft vom Weissen Kreuze, 17-18. 
sezonalnosti koja danas u nas prevladava. Lječilište je bilo zatvoreno samo tijekom srpnja, radi redovitog čišćenja i održavanja. Tipičan boravak gostiju protezao se na četiri tjedna ljeti, odnosno šest tjedana zimi. Cijena boravka uključivala je posteljinu, liječnički pregled glavnog liječnika i lijekove koje on propiše, ali ne i grijanje. Rezervacije su se vodile pri zapovjedništvu 3. korpusa u Grazu. Poznato je da je zapovjednik (komandant) lječilišta u Opatiji 1907. bio c. i k. pukovnik Guido Wachter, zatim Neudecker i na kraju pukovnik Friedrich Röszler, odnosno njegov zamjenik, bojnik Rudolf von Kurz zum Thurn. ${ }^{23}$ Glavni liječnik [Chefarzt] vojnog lječilišta bio je najprije Vatroslav/Igo/Ignaz/Ignjat Schwarz (živio 186r. - I929.; u Opatiji ı886. I893.), ${ }^{24}$ a poslije I897. Franz Tripold (živio I865. - I956., u Opatiji r891. - I947.), inače zet ravnatelja Lječilišnog povjerenstva [Kurkommission] Juliusa Glaxa, glavni liječnik Dobrovoljnoga vatrogasnog spasilačkog društva i osoba koja je vodila brigu o meteorološkoj postaji. ${ }^{25}$

U skladu s općom politikom privlačenja gostiju, Opatija se i potencijalnim gostima vojnog lječilišta prikazivala idealnom za ,bolesti organa krvotoka (kronični miokarditis, masno srce, mane na zaliscima, aterom, srčane neuroze, uključujući Basedowljevu bolest; od listopada do svibnja), funkcionalne i organske živčane tegobe (osobito u vrijeme kupanja u moru i od siječnja do svibnja), kronični katar grla, ždrijela, bronha (u vlažnijim mjesecima - listopadu, studenome, prosincu, ožujku i travnju), katar vrha pluća i kronične infiltracije (u proljeće i jesen kao prijelazna postaja), pleuritični eksudati, škrofuloza, teški oporavak te kao postaja za oporavak i jačanje djece“. Širina ,indikacija“ za spasonosni boravak u Opatiji oslikavala je svakako nepreciznosti medicine toga doba, ali i brojne dijagnoze pod kojima se mogla skrivati tuberkuloza (uobičajeni Spitzenkatarrh, kronične infiltracije pluća, pleuritični eksudati, škrofuloza itd.), uz nespominjanje tuberkuloze i naglašavanje da Opatija u tim slučajevima treba biti „prijelaznom postajom“ (prema južnijim destinacijama - u koje se ubrajao Lošinj jednako kao i Egipat ili Madeira), otkrivajući stari strah opatijskih ugostitelja od tuberkuloze, njezine zaraznosti i odbojnosti (koji je neke goste - poput Franje Ferdinanda odbio, zapravo, od Opatije).

23 K. k. Gesellschaft vom Weissen Kreuze (1917), Jahrbuch der K. k. Gesellschaft vom Weissen Kreuze, 51-54.

24 Više o njemu: Balić, Đ. (2015), Dr. med. Vatroslav Igo Schwarz, prvi osječki planinar, DG Jahrbuch 22 (2015): 375-384.

25 Više o tome: Fischinger, J., Fischinger, A i Fischinger, D. (2012), Dr Franz Tripold (18651956), one of the most important pioneer physicians in Opatija / Abbazia, Acta medico-historica Adriatica 10, br. 1: 45-54. 


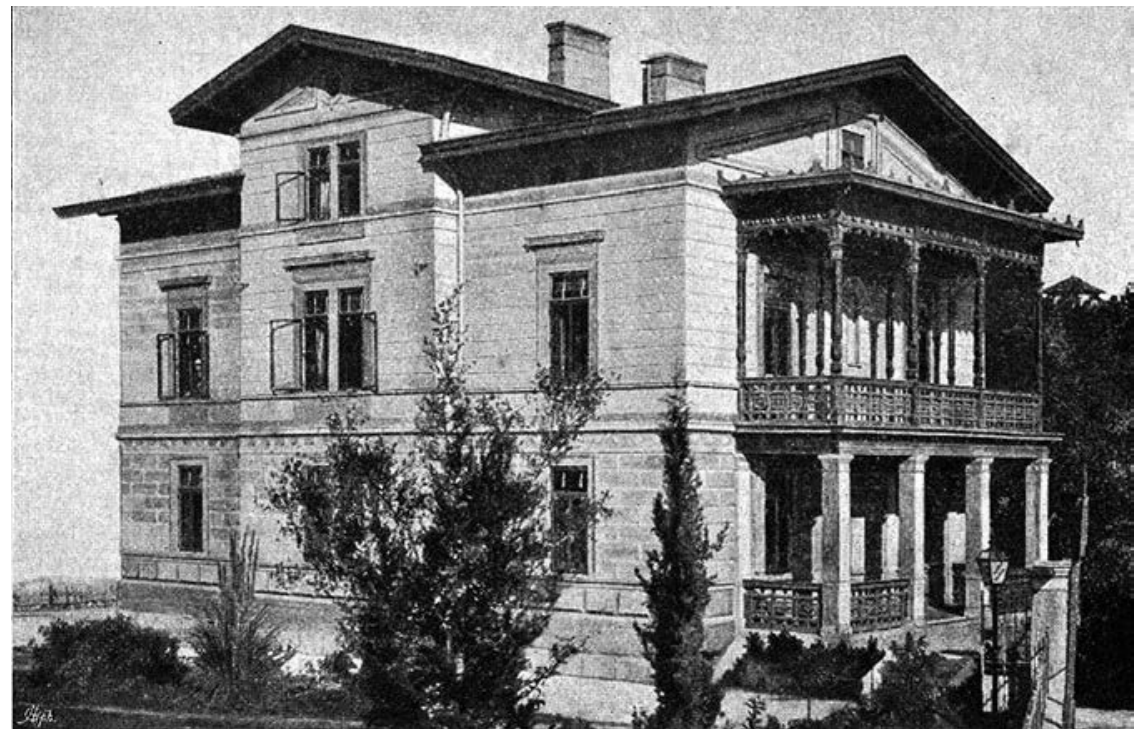

Slika 4. Opatija, Časničko lječilište Društva Bijeli krǐ̌. Izvor: Glax, J. (I9o9.)

Osim glavnih medicinskih tretmana, gostima se nudilo i druge povoljnosti: $15-20 \%$-tni popust u nekim hotelima i pivnicama, $50 \%$-tni popust u ordinaciji zubara Altera, zatvorenom javnom kupalištu Nadvojvoda Ludvig

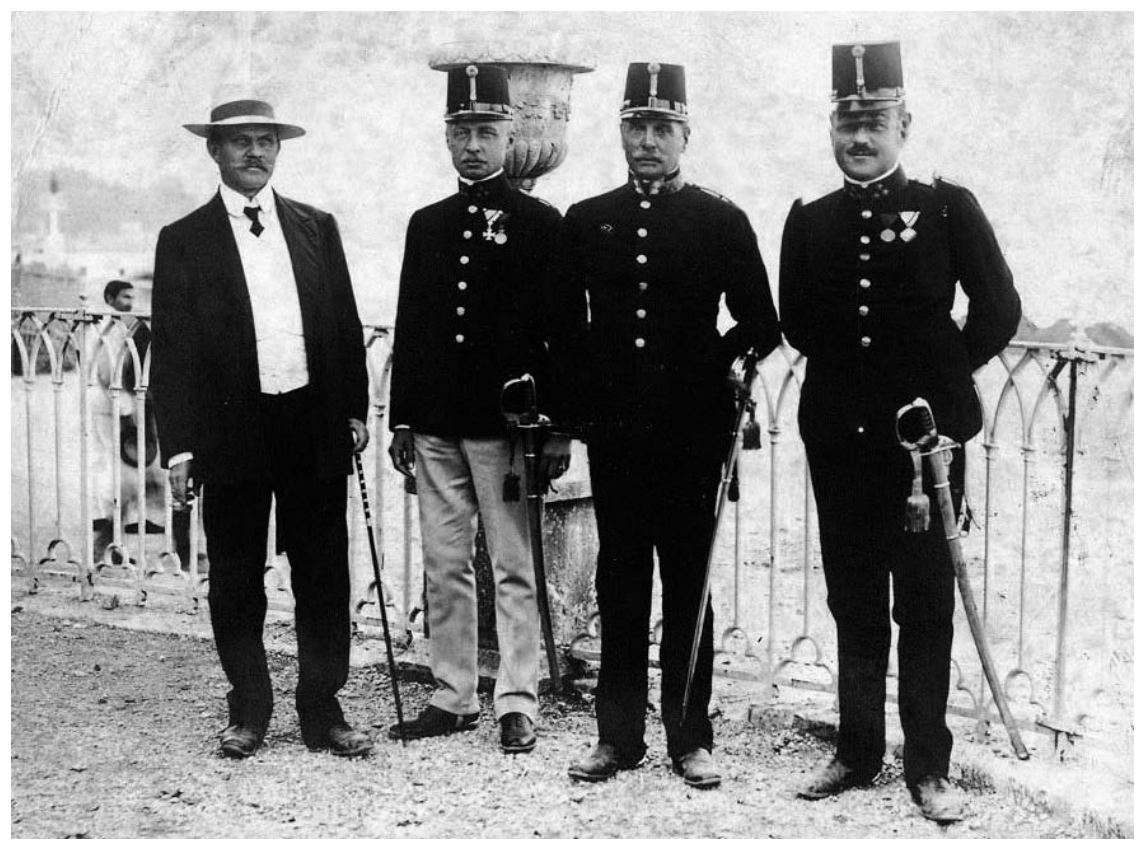

Slika 5. Austrougarski časnici na rehabilitaciji u Opatiji, ıgıo. Izvor: Privatna fotografija autora 
Mnbau an das h: h. R: Ofixiero. Eurbaus in Mbbazix.
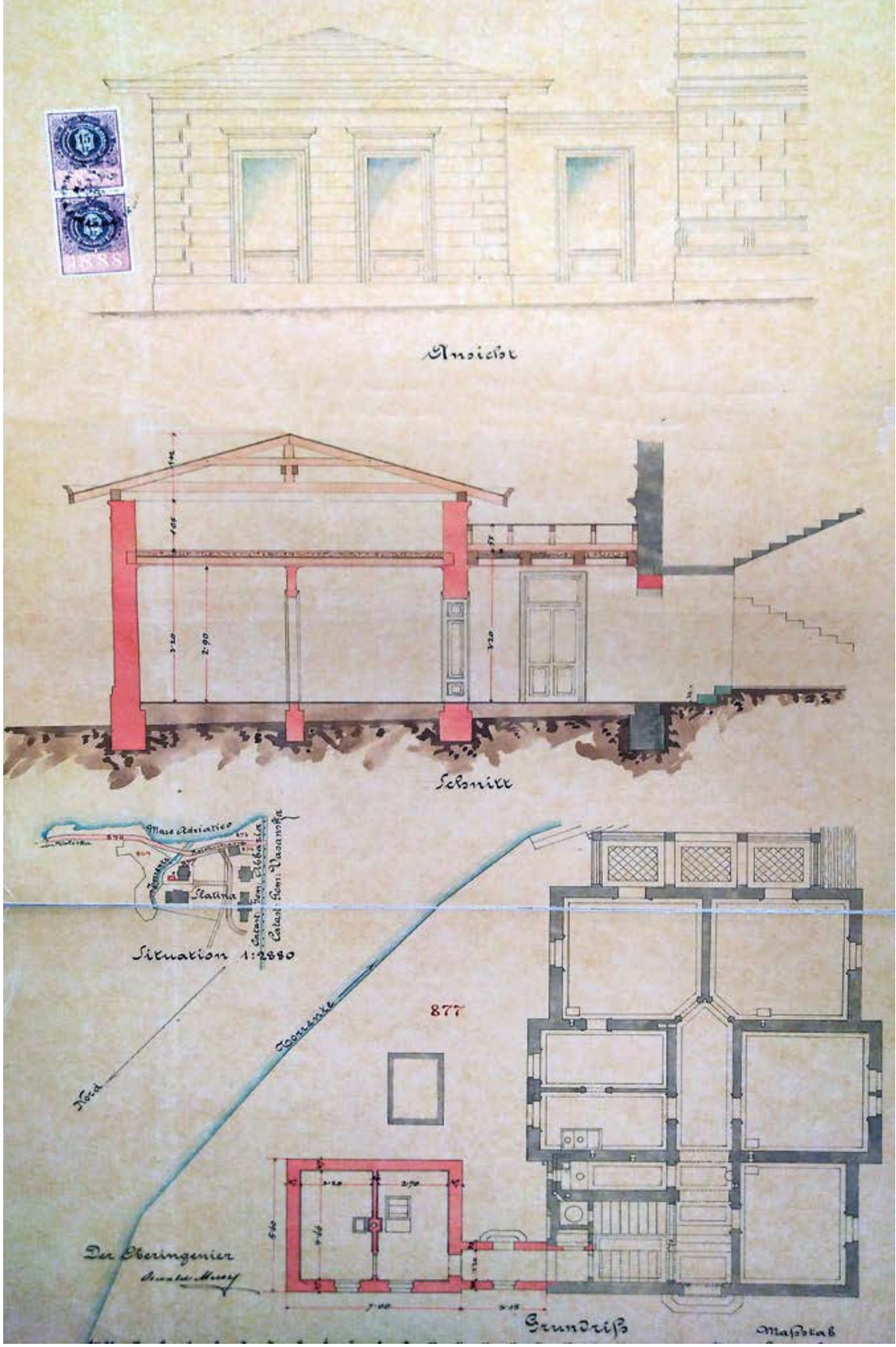

Slika 6. Opatija, Dogradnja časničkog lječilišta Društva Bijeli križ. Izvor: Državni arhiv u Rijeci 
Viktor i svim otvorenim javnim kupalištima, kao i snižene cijene vožnje kočijom od željezničke stanice u Matuljima i do nje. Sve svjedoči tezi da su vojna i druga lječilišta za austrijske uprave u našim krajevima doista bila zdravstvene (dakle, primarno ugostiteljske), a ne samo medicinske ustanove. ${ }^{26}$

Medicinske procedure koje su se pak nudile korisnicima vojnog lječilišta (ne neizbježno u samom objektu, ali u obližnjem zatvorenom Kupalištu nadvojvode Ludviga Viktora i drugdje) bile su vrlo bogata dijapazona, u svakom slučaju šireg nego u ponudi današnjih opatijskih hotela i specijalne bolnice. Tako se u Opatiji na nekoliko mjesta moglo liječiti električnim kupkama (elektrode povezane s izvorom galvanske struje ugrađene su u stijenku porculanske kade) koje su mogle oplahivati čitavo tijelo ili samo kombinacije ruku i nogu (dvije ili četiri kadice). Kupke s dodatkom ugljične kiseline i nekih minerala omogućivale su, vjerovalo se, resorpciju ugljičnog dioksida i posljedičnu neutralizaciju mliječne kiseline u tijelu (koja se otežano odstranjuje pri slaboj cirkulaciji) i veći podražaj centra za disanje (prema tome i bolju respiraciju).Za zračne kupke [Luftperlbad] bilo je karakteristično uvođenje mjehurića zraka u kadu, što je imalo djelovati kao ugodan podražaj i smirivati kupača. Hidropatija je podrazumijevala i različite vrste tuševa (škotski, s izmjenjivanjem toplog i hladnog mlaza; magleni, s vrlo finim štrcanjem itd.), parne kupelji, saunu, obloge i umatanja, trljanja i polijevanja, kupke toplim zrakom [Heissluftbad] aplicirane kao struja na bolesni zglob, kupke s ekstraktima i dodacima mirišljivih soli, eteričnih ulja, norveških algi. Hladne kupke [Kaltbad] značile su nekoliko minuta zagnjurenosti u vodu ohlađenu na Io $-15{ }^{\circ} \mathrm{C}$, a francuske sjedeće kupke s lokalnim tuširanjima (vaginalnim, hemoroidalnim, rektalnim, lumbalnim) danas bismo nazvali Jacuzzi. Kod sjedećih je i stopalnih kupki [Sitzbad, Fußbad] pacijent općenito bio u bačvi angažiran najviše do pupka, ali nije smio čitati budući da su te kupke, kako se objašnjavalo, odvodno sredstvo, a čitanje odvodi krv u mozak i aktivira elektricitet u tom dijelu, dok bi toplina i elektricitet trebali biti „odvedeni dolje“. Ozet-Bäder bile su pak pjenušave kisikom bogate kupelji (po patentu dr. Sarasona) za „srce, krvožilje, bubrege, živce, endokrine i plućne boli“. Nastavilo se i s antičkom praksom peroralne primjene vode. Bavarac Örtel, koji se ubraja i u opatijske promotore, lansirao je devizu da hladnu vodu treba piti "preko mjere", a kupati se u njoj dok se ne poplavi [Kaltwassertrinken bis zum Übermaß und Kaltwasserbaden bis zum Verblauen]. Od dijetetskih su se metoda u Opatiji oglašavale i kure kefirom (protiv kroničnog zatvora i kod

26 Cf. Kranjčević, J. (2016), Vojna lječilišta Društva Bijeli križ na istočnoj obali Jadrana, DG Jahrbuch, 23, 75-88. 
bezmesne dijete), mlijekom (kod akutnih i kroničnih bolesti bubrega) i grožđem (Traubenkuren: do $3 \mathrm{~kg}$ grožđa na dan kao diuretik i purgativ, kao lijek protiv gihta, bolesti žučnjaka, bubrega i jetre, opstipacije). U sanatorijima se primjenjivala i pneumatska inhalacija (inhaliranje komprimiranog zraka kod atelektaza, kroničnog bronhitisa, astme i emfizema), inhalacija kisika (više puta dnevno po desetak minuta, kod smetnji cirkulacije i stenoza dišnih putova), morskog aerosola (jodu se pripisivao prevelik učinak sve dok nije dokazano da je riječ o elementu u mikrokoličinama) i eteričnih ulja kod bolesti respiratornog trakta (to se sve manje-više i danas koristi). Zračenje izotopa torija ili radija ili pak rendgensko olako se propisivalo kod ekcema, psorijaze, madeža, tumora i keloida, ali i kod povišenog tlaka, potkrijepljeno dokazima da se nakon svake seanse može registrirati pad tlaka (vjerojatno zbog redistribucije krvotoka prema periferiji). Arsonvalizacija (po d'Arsonvalu, I892., ili teslinizacija: struja visoke frekvencije i napona, ali male jakosti) koristila se za jačanje srca, protiv anginoznih bolova, nesanice i glavobolje, povišenog tlaka (danas se smatra da arsonvalizacija može razviti samo toplinu na površini tijela, neznatnu za terapijski učinak, pa je zamijenjena kratkovalnom dijatermijom). Zračilo se i ultraljubičastim svjetlom (lokalno kod neuralgija, mialgija i dermatoza, generalno kod gihta, dijabetesa, astme, hipertenzije itd.), plavim svjetlom, liječilo fototerapijom po Finsenu (kod kožne tuberkuloze), gimnasticiralo se kod ravnih stopala, kifoze i dismenoreje, uvježbavale se tehnike disanja, masiralo se glađenjem, ribanjem, češljanjem, tučenjem i tresenjem ne samo mišića, kostiju i kože već i izlazišta živaca, prsiju i srca. Postojala je i famozna Thure-Brandt-masaža pri kojoj se lijevi maserov prst gurao u vaginu prema međici (kod djevica se uvodio u rektum), a desna je ruka pritiskala simfizu, čime se navodno masiralo sve dijelove uterusa. Po načelima koja su zacrtali Munde i Örtel pristupalo se terapiji kretanjem: redovito, najprije kraće šetnje, nikad do iscrpljenja, nikad odmah nakon obroka, može se kombinirati s plivanjem i veslanjem, a sve to da bi se ubrzao ritam metabolizma, probave, ojačali mišići i kardiovaskularni sustav. ${ }^{27}$

Vojno ili časničko lječilište u Opatiji bilo je prezentirano i reklamirano u različitim turističkim vodičima i časopisima - u Stradners Adria Führer za ljeto 1907./I908. i 1909., zatim u raznim izdanjima Wintercurort und Seebad Abbazia - ein Führer für Curgäste, Kur-und Bade-Zeitung der österreichischen Riviera iz

27 Dio o opatijskim hidropatskim i drugim lječilišnim procedurama preuzet je iz: Muzur, A. (1998) Kako se stvarala Opatija: prilozi povijesti naseljavanja, grada $i$ zdravstvenog turizma (Opatija/Rijeka: Katedra Čakavskog sabora Opatija/Grad Opatija/Naklada Benja, $150-155$. 
1907., Illustrierter Führer durch Dalmatien iz I9ı2., u časopisu Fremdenverkehr i drugdje.

Prva zgrada vojnog lječilišta u Opatiji imala je visoko prizemlje, kat i nisko potkrovlje. Ulično pročelje bilo je dužine $\mathrm{I7}$ metara. U zgradi se nalazilo 2 velikih soba s centralnim grijanjem i dvjema kabinama u prizemlju. U prizemlju zgrade nalazila se kancelarija za prijam i evidenciju gostiju te stan „kućnog zapovjednika" [Hauskommandant] i kuhinja. Na prvom katu nalazilo se pet velikih soba, a na drugom katu tri velike i dvije male sobe. Strana zgrade orijentirana prema moru tijekom toplih dana stvarala je posebnu ugodu sa zasjenjenom verandom u prizemlju i balkonom na katu oslonjenom o četiri stupa. Dodatna ponuda vojnom lječilištu bile su šetnice uz more, teniska igralište, liječničke usluge u drugim zdravstvenim objektima, čitaonice itd. Usprkos malom smještajnom kapacitetu vojnog lječilišta u Opatiji, broj gostiju/pacijenata značajno je rastao: dok ih je u prvoj godini bilo svega 7 , 19I3. ih je bilo već 77. Najveći broj gostiju zabilježen je r9ıo., kada ih je u lječilištu boravilo 124 .

Veličinom nezadovoljavajuće, vojno lječilište je potkraj ıgı6. srušeno, da bi na njegovu mjestu bilo podignuto znatno veće (za 58 - 60 gostiju), prema projektu Aloisa von Wurm-Arnkreuza. Lječilište je, po novoj austrijskoj carici, nazvano Kaiserin-Zita-Offizierskurhaus [Časničko lječilište carice Zite]. ${ }^{28}$

Nova zgrada lječilišta imala je prizemlje, 3 kata i potkrovlje. Već iz samog volumena vidljivo je značajno povećanje smještajnog kapaciteta. Restoran i sobe za druženje trebali su imati 60 sjedala. ${ }^{29} \mathrm{U}$ prizemlju su trebale biti sve servisne i upravne prostorije lječilišta te liječničke ordinacije.

\section{Vojno lječilište Društva Bijeli križ I liječnici na Lošinju}

Začeci turizma na otoku Lošinju vežu se uz obitelj Habsburg i vojsku, točnije, uz mornaricu. Nadvojvoda Karlo Stjepan von Habsburg, kao zapovjednik austrougarske ratne mornarice, u Velom Lošinju kupio je i885. zemljište te sagradio svoj rezidencijalni ljetnikovac/zimovnik, vilu Wartsee, ${ }^{30}$

28 Ovo će zdanje doživjeti nekoliko preinaka: u vrijeme talijanske uprave bit će spojeno $\mathrm{s}$ hotelom Slatina u hotel Continentale, a i nakon Drugoga svjetskoga rata će, do 1970., nekoliko puta mijenjati izgled i obujam. U vrijeme Domovinskog rata ugostit će prognanike, potom dugo stajati zatvorenim, da bi u ožujku 2013. dio koji je zauzimalo vojno lječilište bio srušen, a na njegovu mjestu uređeno parkiralište.

29 K. k. Gesellschaft vom Weissen Kreuze (1917), Jahrbuch der K. k. Gesellschaft vom Weissen Kreuze, 51.

30 Vila Wartsee je 1889. pretvorena u javno klimatsko lječilište, odnosno bolnicu za dječje bolesti (za skrofuloznu i slabunjavu djecu). 
kraj kojega je podignuo velik perivoj koji je dovršen I89o. godine. Zanimljivo je da je i drugi austrijski nadvojvoda, Maksimilijan Habsburški (mlađi brat cara Franje Josipa I.), admiral austrougarske ratne mornarice, poslije car Meksika, I886. položio kamen-temeljac za gradnju lukobrana i obalnog puta od Rovenske do uvale Kriška (dužine oko $3 \mathrm{~km}$ ). Austrougarski prijestolonasljednik Rudolf posjetio je Lošinj 1887., a za njegov posjet uređen je planinarski put za Osoršćicu, kojim se popeo. ${ }^{31}$

Za proglašenje Lošinja klimatskim lječilištem veliku zaslugu svakako ima grupa liječnika s bečkog Sveučilišta koja je početkom travnja 1886. posjetila Lošinj: dvorski savjetnik prof. dr. L. von Schrötter, prof. dr. J. Weinlechner, prof. dr. J. Gruber i dr. R. Lang. Te iste I886. dr. Conrad Clar iz Graza objavio je članak Drei Winterwochen auf der Insel Lussin [Tri zimska tjedna na otoku Lošinju] u časopisu Österreichische Badezeitung: Organ für die Interessen der europäischen Kurorte und des Kurpublikums (sv. 15., br. 9, I3. lipnja 1886., str. 77-79).

Sedam godina poslije, u rujnu I892., Veli Lošinj proglašen je „klimatskim zdravstvenim lječilištem," na prijedlog dr. Conrada Clara i prof. dr. Leopolda von Schröttera, a temeljem praćenja klimatskih podataka koje je sakupio Ambroz Haračić32.

Za potrebe izgradnje zgrade časničkog lječilišta, u Malom Lošinju je I9o3. osnovana podružnica Društva Bijeli križčiji su članovi bili ugledni Lošinjani iz obitelji Cosulich, Cattarinich, Martinolich, Premuda, Tarabochia, Starcich, Gerolimich i drugi. Osim Lošinjana, članovi Društva bili su Iginio Scarpa i Nikolaus Chorinsky iz Opatije. ${ }^{33} \mathrm{U}$ financiranju izgradnje sudjelovao je

31 Uređenje planinarskih staza obogaćuje ponudu turističke destinacije.

32 Haračić, Ambroz, hrvatski botaničar i meteorolog (Mali Lošinj, 5. 12. 1855 - Mali Lošinj, 1. 10. 1916). U Beču studirao filozofiju, matematiku i kemiju, radio kao nastavnik na pomorskim školama u Trstu i u Malom Lošinju gdje je predavao fiziku, meteorologiju i parne strojeve. Godine 1897. premješten je u Trgovačko-pomorsku akademiju u Trst gdje je ostao do 1905. kada se ponovno vratio u Mali Lošinj. U studenom 1879. započeo sustavna mjerenja na svojoj meteorološkoj postaji, koja je od 1880. dobila službeni status, a dvije godine poslije postala Meteorološki opservatorij Pomorske škole u Malom Lošinju. Na temelju njegovih podataka Mali i Veli Lošinj postali su 1892. klimatskim lječilištima. Glavno djelo: Otok Lošinj, klima i vegetacija (L'isola di Lussin, il suo clima e la sua vegetazione, 1906). Svi floristički podatci dokumentirani su herbarskom zbirkom, koja se nalazi u Hrvatskom herbariju Botaničkoga zavoda Prirodoslovno-matematičkoga fakulteta u Zagrebu. Cf. Penzar, I. (2002), Haračić, Ambroz, u: Hrvatski biografski leksikon, Trpimir Macan (ur.), Zagreb, Hrvatski leksikografski zavod Miroslav Krleža.

33 K. k. Gesellschaft vom Weissen Kreuze (1912), Jahrbuch der K. k. Gesellschaft vom Weissen Kreuze, Wien, 19. 


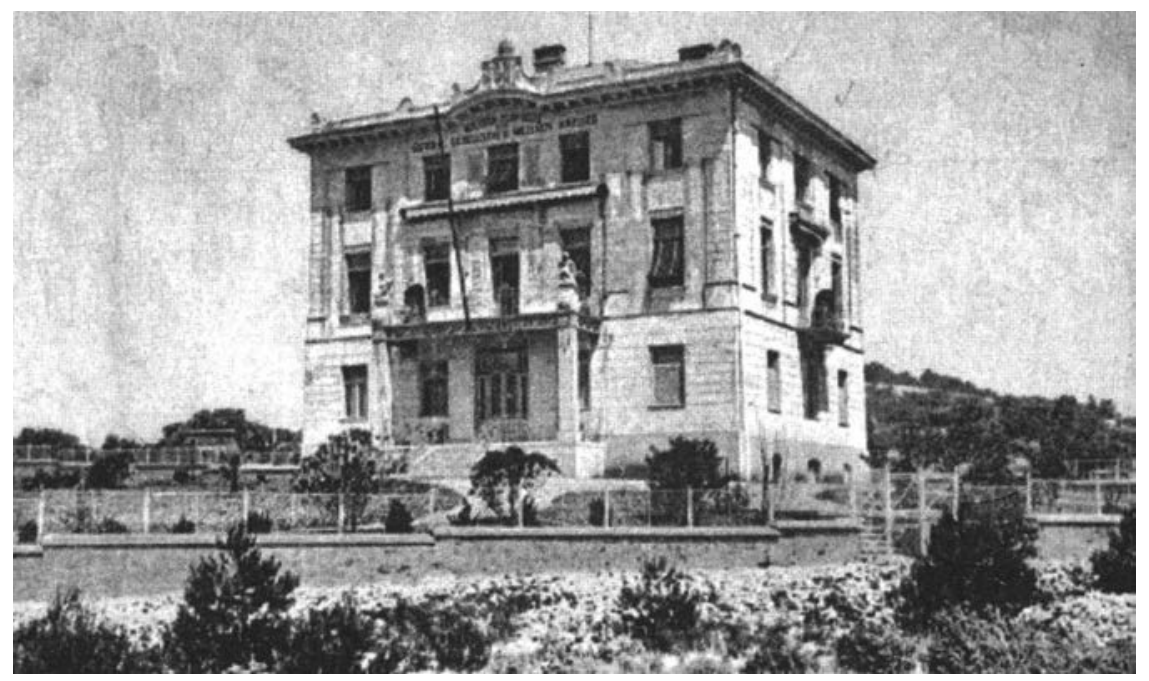

Slika 7. Mali Lošinj, Časničko lječilište Društva Bijeli križ. Izvor: Dlaka, I. i Gović, V. (ur.) (20I2.)

bečki bankar Rothschild, a svečanom otvaranju prisustvovao je i general Oskar Potiorek. ${ }^{34}$

Prema podacima iz različitih turističkim vodičima, od liječnika su 1907. u Malom Lošinju radili E. Barac, G. Cattarinich, V. Gramaticopolo, R. Hájos, N. Martinolich, F. Veth i L. Wobr. ${ }^{35}$ Godinu dana kasnije, u Malom Lošinju radili su V. Bolmarcich, G. Cattarinich, C. Cega, R. Hájos i F. Veth. ${ }^{36}$ U Velom Lošinju pak djeluju J. Simonitsch i D. Sussich. ${ }^{37}$ Godine I909. u Malom Lošinju djeluju V. Bolmarcich, F. Cleva, R. Hájos i F. Veth. ${ }^{38}$ Godine I9ı 2. liječnici u Malom Lošinju su F. Veth, G. Cattarinich, F. Cleva, F. Wobr i R. Hájos.

Časničko lječilište Društva Bijeli križ u uvali Čikat na otoku Lošinju ${ }^{39}$ izgrađeno je I907. prema projektu koji je potpisao c. i k. građevinski savjetnik arhitekt Alois Maria Wurm von Arnkreuz.

U prizemlju zgrade nalazio se stan zapovjednika (komandanta) te dvije jednokrevetne i jedna dvokrevetna soba. Na prvom katu nalazila se soba za

34 Dlaka, I. i Gović, V. (ur.) (2012), Lošinjski hoteli, pansioni i lječilišta 1887.-2012., Mali Lošinj, $152-153$.

35 Stradner, J. (1907/08), Stradners Adria-Führer insbesondere Anzeiger der Seebäder und Luftkurorte an der Adria, Graz, 20.

36 Ibid., 31.

37 Ibid., 36.

38 Stradner, J. (1909), Stradners Adria-Führer insbesondere Anzeiger der Seebäder und Luftkurorte an der Adria Graz, 33.

39 *** (1908), Seebad und Winterkurort Cigale bei Lussinpiccolo, Fremenverkehr 24, 3-7. 
čitanje, zatim šest jednokrevetnih soba i jedna dvokrevetna. Na drugom katu nalazilo se osam jednokrevetnih soba i jedna dvokrevetna. Oko zgrade bio je vrlo lijepo uređen vrt. ${ }^{40}$ Krovni vijenac iznad glavnog ulaza bio je ukrašen carskim i kraljevskim grbom. Glavni ulaz u zgradu bio je natkriven balkonom koji je bio poduprt dvama stupovima. Glavni balkon krasile su dvije skulpture i kovana ograda. Zaštitu od sunca na prvom katu prozora činilo je pokretno platneno sjenilo. Na ulazu zgradu je krasila kovana ograda stubišta oblikovana elementima secesije, koja je vodila u visoko prizemlje. Parcela vojnog lječilište bila je ograđena i uređena zasađenim zelenilom. Zapovjednik zgrade bio je c. i kr. kapetan korvete R. Eduard Unschuld, a glavni liječnik Rudolf Hatschek. ${ }^{41}$

Za liječenje u ovoj ustanovi isticane su kao glavne indikacije „skrofuloza (kožne promjene, upale limfnih čvorova i dr.), gljivična i karijesne bolesti zglobova i kostiju, lues, gonoreja“ i dr. Lječilišnom sezonom smatralo se razdoblje od I. svibnja do I. listopada. Zapovjednikom doma bio je oko I9o9. pukovnik Vinzenz pl. von Traun, a glavni liječnik Josef Haidenthaller. U kasnijim reklamnim materijalima kao indikacije za boravak u Lošinju dodan je i „katar gornjih dišnih putova, tuberkuloza kostiju, zglobova i žlijezda, početni stadij tuberkuloze pluća [Lungenspitzenkatarrh], neurastenija i histerija, smetnje cirkulacije i metabolizma, bolesti krvi i lokomotornog sustava, ženske bolesti, eksudati“ i dr., a spominjalo se i da je časničko lječilište otvoreno od I. siječnja do 28. listopada. Zapovjedništvo nad zgradom preuzeo je (IgI2.) bojnik Karl Kozurik, a mjesto glavnog liječnika Rudolf Hájos. Kozurika će oko I917. zamijeniti potporučnik Karl Thierry.

U Malom Lošinju časnici su mogli biti smješteni i liječeni i u sanatoriju dr. Rudolfa Hájosa koji je I909. tu bio glavni liječnik. ${ }^{42}$

Zgrada je tijekom više rekonstrukcija ostala bez atraktivnih ornamenata na pročelju i na velikoj terasi iznad glavnog ulaza. ${ }^{43}$

Od izgradnje 1907. vojnog lječilišta Društva Bijeli križ u Malom Lošinju do I9I3. u zgradi je boravilo ukupno 968 osoba. Najveći broj zabilježen je I9ı2. kada je u lječilišstu boravilo 2ı4 gostiju.

\footnotetext{
Danas je vrt zarastao u borove i gotovo neprepoznatljiv.

Ibid, Jahrbuch, 52.

42 K. k. Gesellschaft vom Weissen Kreuze (1917), Jahrbuch der K. k. Gesellschaft vom Weissen Kreuze, Beč.

43 Zgrada je zapuštena i više godina nije u funkciji zbog neriješenih vlasničkih odnosa, što je utvrđeno uvidom na terenu u lipnju 2018., a provjereno 2020. u kontaktu s Lošinjskim muzejom.
} 


\section{ZAKLJUČAK}

Ovo istraživanje pokazalo je da je briga o unapređenju zdravlja vojske (osobito časnika) u Austro-Ugarskoj Monarhiji od sredine 19. stoljeća sve više dobivala na medicinskom i na društvenom značenju.

Jedan segment brige o unapređenju zdravlja časnika u austrijskom dijelu Monarhije preuzelo je Društvo Bijeli križ koje je angažiralo na suradnju liječnike i arhitekte. Društvo se pokazalo opravdanim ne samo zbog brige i provođenja unapređenja zdravlja vojske već i zbog pozitivnog poslovanja.

Časnička lječilišta, Društva Bijeli križ, u Opatiji i u Malom Lošinju volumenom i kapacitetom mogu se okarakterizirati kao manja (nalik onima u Portorožu, Ilidži i Rogaškoj Slatini) u odnosu na ona izgrađena na prostoru današnje Češke, Austrije, Njemačke i Italije.

Najveći dio brige o unapređenju zdravlja časnika bio je usmjeren na pružanje medicinskih i zdravstvenih usluga, ali i na društveni kontakt sa zajednicom. Budući da su časnici imali visok položaj u društvu, odabir lokacije trebao je ukazati na njihov status, stoga su zgrade građene u prestižnim lječilištima.

Zgrade su zadovoljavale tadašnje medicinsko-lječilišne standarde za boravak u zatvorenom (sobe, sanitarije, ordinacija, kuhinja i dr.) i otvorenom prostoru (nadstrešnice, pergole, vrtovi, parkovi). S obzirom na to da je riječ o zgradama specifične lječilišno-smještajne namjene, one su istodobno trebale zadovoljiti higijenske, društveno-javne i servisno-upravne ${ }^{44}$ funkcije. $U$ tim se zgradama velika pažnja posvećivala i kvalitetnoj tehničko-tehnološkoj opremljenosti (rasvjeta, grijanje, odvodnja, opremljenosti kuhinje), ali i vanjskom oblikovanju jer je ono odražavalo društveni status vojske.

S obzirom na to da su uglavnom projektirane i građene krajem Ig. i početkom 20. stoljeća, zgrade lječilišta u vanjskom oblikovanju nose obilježja historicizma. S današnjeg aspekta bile su razmjerno malog volumena i smještajnih kapaciteta, posebno u odnosu na kapacitete reprezentativnih hotela (npr. Kvarner). Ali cilj je bio omogućiti časnicima očuvanje i unapređenje zdravlja suvremenim metodama i uslugama u samim zgradama ili specijaliziranim proglašenim lječilištima. Nažalost, zgrade lječilišta nisu bile prilagođene osobama smanjene pokretljivosti, ali su nudile mogućnost korištenja pratnje.

44 Servisno-upravne funkcije podrazumijevaju kuhinjski pogon, upravni dio (administracija), servis, osiguranje grijanja, zbrinjavanje otpadnih voda i otpada. 
Iz sačuvanih tekstova, fotografija i crteža zaključuje se da se velika pažnja posvećivala uređenju zelenih površina ne samo kao elementu zaštite od sunca već i radi ostvarenja estetskog aspekta. Premda nisu bila otvorena za „obične turiste“, tj. javnost, vojna lječilišta bila su navođena u turističkim vodičima i opisima naselja te predstavljena u turističkim i arhitektonskim časopisima.

Opisana istraživanja nipošto ne iscrpljuju temu i nesumnjivo pridonose saznanjima o razvoju lječilišnog turizma, povijesti medicine, povijesti lječilišne arhitekture na Kvarneru i hrvatskom Jadranu.

\section{LITERATURA I IZVORI}

1. *** (1888), Das neue Officier-Curhaus in Abbazia, Wiener Bauindustrie Zeitung, $\mathrm{VI}(2), 15$.

2. *** (1892), Wohngebaude in Slatina, Abazia, Allgemeine Bauzeitung 57, Tafel 23.

3. *** (1907), Rundgang durch Abbazia Humanitäranstalten, Kur-und Bade-Zeitung der österreichischen Riviera 2(19),1-3.

4. *** (1908), Seebad und Winterkurort Cigale bei Lussinpiccolo, Fremenverkehr 24, 3-7.

5. *** (1909), „Cirkvenica - Seebad und klimatischer Kurort“, Fremdenverkehr 16, 4.-6.

6. *** (2012), Lošinjski hoteli, pansioni i lječilišta 1887.-2012., Dlaka, I. i Gović, V. (ur.), Lošinjski muzej, Mali Lošinj.

7. Balić,Đ. (2015), Dr. med. Vatroslav Igo Schwarz, prvi osječki planinar, Godišnjak Njemačke narodnosne zajednice/DG Jahrbuch 22, 375-386.

8. Blažević, I. (1987), Povijest turizma Istre i Kvarnera, Otokar Keršovani, Opatija.

9. Clar, C. (1886), Drei Winterwochen auf der Insel Lussin, Österreichische Badezeitung-OrganfürdieInteressen der europäischen Kurorte und des Kurpublikums 15(9), 77-79.

10. Dugački, V. (2010), Medicinska periodika u Hrvatskoj do 1918. Godine, Studia lexicographica: časopis za leksikografiu i enciklopedistiku 41(6), 115-137.

11. Fischinger, J., Fischinger, A., Fischinger, D. (2012), Dr Franz Tripold (1865-1956), one of the most important pioneer physicians in Opatija/Abbazia, Acta medico-historica Adriatica 10(1), 45-54.

12. Glax, J. (1909), Wintercurort und Seebad Abbazia - ein Führer für Curgäste, Abbazia.

13. Glax, J. (1909), Zimsko lječilište i morsko kupalište Opatija: Putovogja za lječilišne gostove, Opatija.

14. K. k. Gesellschaft vom Weissen Kreuze (1909), Jahrbuch der K.K. Gesellschaft vom Weissen Kreuze, Beč.

15. K. k. Gesellschaft vom Weissen Kreuze (1912), Jahrbuch der K.K. Gesellschaft vom Weissen Kreuze, Beč. 
16. K. k. Gesellschaft vom Weissen Kreuze (1914), Jahrbuch der K.K. Gesellschaft vom Weissen Kreuze, Beč.

17. K. k. Gesellschaft vom Weissen Kreuze (1917), Jahrbuch der K.K. Gesellschaft vom Weissen Kreuze, Beč.

18. Kranjčević, J. (2016), Vojna lječilišta Društva Bijeli križ na istočnoj obali Jadrana, Godišnjak njemačke zajednice/DG Jahrbuch 23, 75-88.

19. Lipovšćak, Đurđa (2002), Put kroz milenije, Topusko kratka povjesnica, Topusko.

20. Muzur, A. (1998), Kako se stvarala Opatija: prilozi povijesti naseljavanja, grada $i$ zdravstvenog turizma, Katedra Čakavskog sabora Opatija/Grad Opatija/Naklada Benja, Opatija/Rijeka.

21. Penzar, I. (2002), Haračić, Ambroz, Hrvatski biografski leksikon, Trpimir Macan (ur.), Zagreb, Hrvatski leksikografski zavod Miroslav Krleža.

22. Radović Mahečić, D. (2002), Preobrazba Opatije 1882.-1897.: počeci turističke arhitekture, Radovi IPU 26, 132-148.

23. Reimer, H. (1889), Handbuch der speciellen Klimatotherapie und Balneotherapie mit besonderer Rücksicht auf Mittel-Europa zum Gebrauch für Aerzte, Berlin.

24. Rr.G.v.Z. (1911.), Seebäder und Winterstationen, Adria, Triest, III (8), 315-316

25. Stradner, J. (1907), Anzeiger der Seebäder und Luftkurorte an der Adria, Graz.

26. Stradner, J. (1907/1908), Stradners Adria-Führer insbesondere Anzeiger der Seebäder und Luftkurorte an der Adria, Leykam, Graz.

27. Stradner, J. (1909), Stradners Adria-Führer insbesondere Anzeiger der Seebäder und Luftkurorte an der Adria, Leykam, Graz.

28. Uremović, V., Vukelić, I., Gobić, J. (2006), Počeci i razvoj talasoterapije i zdravstvenog turizma u Crikvenici, Acta medico-historica Adriatica, 4(2), 247-258

29. Zakošek, B. (2005), Opatijski album, Državni arhiv Rijeka, Rijeka.

\section{Summary}

The health of officers (as well as the entire army) is exposed to additional risks due to the performance of various life-threatening tasks for the needs of the state. Therefore, it is not unusual for the state to take care of the health of its officers (as well as the army) through a system of Vojvodina medical care or specialised society through the construction of military or officer health resorts [Militärkurhaus / Offizierskurhaus] with the provision of medical/ health services. The subject of this paper is the relationship between architecture and the provision of military-medical services of officer/military health resorts built by the Society of the White Cross [Gesellschaft vom Weißen Kreuze] in Kvarner at the end of the $\mathrm{I}^{\text {th }}$ and the beginning of the $20^{\text {th }}$ century. The research is based on data collected from Austrian architectural, medical and tourist magazines and yearbooks of Austrian Society of the White Cross. The results of the research contribute to a better understanding of the improvement of the health of officers, the development of the architecture of health buildings [Kurhaus] and the entire history of medicine and health tourism in the Croatian Adriatic.

Keywords: history of medicine, health tourism, military health resorts, Austrian Society of the White Cross, Opatija, Mali Lošinj 